\title{
Antimicrobial Activities of Fungus Comb Extracts Isolated From Indo- Malayan Termite Macrotermes Gilvus Mound
}

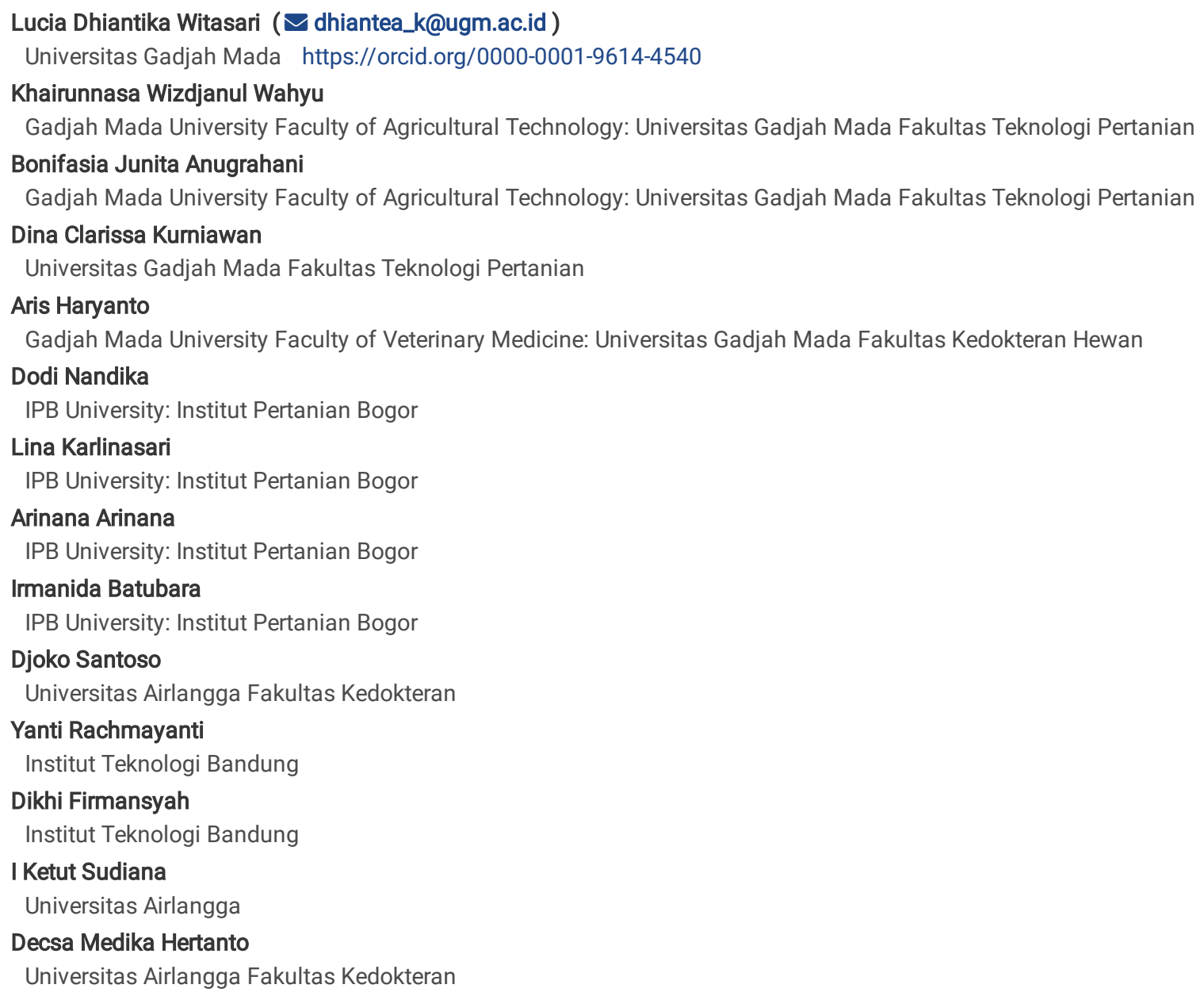

Original article

Keywords: Macrotermes gilvus Hagen, fungus comb extracts, antibacterial, antifungal

Posted Date: December 14th, 2021

DOI: https://doi.org/10.21203/rs.3.rs-1159665/v1

License: (ㅇ (i) This work is licensed under a Creative Commons Attribution 4.0 International License. Read Full License 


\section{Abstract}

The embodiment of antimicrobial components into the food packaging material has the ability to prevent microbial contamination. Fungus comb could be an alternative source of natural antimicrobial agents. In this study, n-hexane, ethyl acetate, methanol, and water extracts from fungus comb isolated from Indo-malayan termite Macrotermes gilvus Hagen mound were analysed for its antibacterial and antifungal activities against food spoilage microorganisms, including Escherichia coli ATCC 25922, Pseudomonas aeruginosa ATCC 27853, Staphylococcus aureus ATCC 25923, Aspergillus flavus, and Aspergillus niger. The antimicrobial activity of the fungus comb extracts was evaluated using Kirby-Bauer disc diffusion and microdilution method. The result showed that ethyl acetate extract exhibited the biggest diameter inhibition zone for all bacteria and fungi tested. Ethyl acetate extract showed antibacterial activity in all bacteria with minimum inhibitory concentration (MIC) and minimum bactericidal concentration (MBC) values of $0.39 \mathrm{mg} / \mathrm{mL}$ and $0.78 \mathrm{mg} / \mathrm{mL}$, respectively. This extract also inhibited $A$. flavus and $A$. niger with $\mathrm{MIC}$ value of $0.78 \mathrm{mg} / \mathrm{ml}$. Ethyl acetate extract contained guaiacol and syringol, which were predicted as the main antimicrobial components in fungus comb. Whereas $\mathrm{n}$-hexane extract only inhibited Gram-positive bacteria. S. aureus ATCC 25923 was the most sensitive bacteria tested using all extracts. In addition, $A$. flavus was more sensitive compared to A. niger. Overall, fungus comb extract exhibited antimicrobial activity against E.coli ATCC 25922 , P. aeruginosa ATCC 27853, S. aureus ATCC $25923, A$. flavus, and A. niger. This study revealed that the fungus comb extract, especially ethyl acetate, could be considered as a new antimicrobial agent.

\section{Key Points}

- Ethyl acetate extract of fungus comb exhibited high antimicrobial activity against S. aureus ATCC 25923, E. coli ATCC 25922, P. aeruginosa ATCC 2785, A. flavus FNCC 6181, and A. niger FNCC 6114.

- Ethyl acetate extract of fungus comb contained phenolics compound of guaiacol and syringol, predicted as important antimicrobial substances.

- S. aureus ATCC 25923 was the most sensitive bacteria tested using n-hexane, ethyl acetate, methanol, and water extracts from fungus comb

\section{Introduction}

Fruits and vegetables are well-known as essential components of a healthy diet. Recently, fresh fruits and vegetables have been associated with diverse foodborne illness outbreaks in many countries. Fruits and vegetables are usually quite acidic and hence quite resistant to invasion by fungi and bacteria. The fruit and vegetable commodities commonly affected by fungi, especially Aspergillus flavus and Aspergillus niger are corn, tomatoes, grape, strawberries, figs, peaches, pears, apples, citrus, melons, and mangoes (Bui-Klimke and Wu, 2016). A. flavus is a well-recognized producer of aflatoxin, and A. niger is known as ochratoxin producer (Pfliegler et al. 2020). In addition, fresh herbs like basil, parsley, and leafy greens, especially spinach and lettuce, are noteworthy potential sources of bacterial contamination (FAO/WHO, 2008). Denis et al. (2016) reported bacterial infections in fresh vegetables and fruits at retail in Canada were identified as Escherichia coli, Salmonella, and L. monocytogenes. Other pathogenic bacteria that often contaminate food are Staphylococcus aureus, and Pseudomonas aeruginosa.

The microbial attack on food products can occur during pre-harvest, transportation, storage, and food processing (Bbosa et al. 2013). In tropical countries, the risk of contamination in postharvest is much higher than in the field due to warm and humid environments. Therefore, it is essential to maintain the temperature remain low between $2-3{ }^{\circ} \mathrm{C}$ and relative humidity around $90 \%$ and $95 \%$ to avoid decay-causing fungi (Boer et al. 2009). Although much effort has been made to adjust the environment, some fruits and vegetables have a high susceptibility to mechanical damage during transportation and chance of atmospheric damages due to oxygen levels decreasing and carbon dioxide increasing. According to Feliziani and Romanazzi (2016), the consumer request for new technologies of fruit and vegetable packaging which are safe and environmentally friendly has increased significantly, such as the application of edible or biodegradable coatings. In addition to a barrier to mechanical injury, the coating can be injected by antimicrobial agents that can inhibit the growth of any food spoilage fungi and bacteria. Therefore the use of antimicrobial agents in food packaging has become a potential solution for preventing more postharvest losses.

Natural products are the most abundant source of antimicrobials. Fungus combs as a natural product are able to minimize potentially pathogenic fungi and are competitive in the environment to maintain the health of their colonies (Arango, 2015). Fungus comb is a special structure created by termite colonies from the sub-family Macrotermitinae (Isoptera: Termitidae) in their nests as a substrate for the growth of the only one fungus species, Termitomyces sp. (Arshad and Schnitzer 1987, Arinana et al. 2016). It is proposed that chemical compounds in the fungus comb might suppress the growth of another species. Therefore, fungus comb is a potential candidate as a source of active compounds for an organic antimicrobial agent. In a previous study, Nandika et al. (2021) extracted and determined the chemical components of fungus comb from Indo-Malayan termite Macrotermes gilvus Hagen (Isoptera:Termitidae). It is composed phenol, hydroquinone, steroids, terpenoids, and saponin compounds. The study also showed that ethyl acetate extract inhibited the growth of Aspergillus foetidus, a fungus that attacks wooden raw materials, including rubberwood (Hevea brasiliensis Muell. Arg.). However, the bioactivity of fungus comb extract from Indo-malayan termite Macrotermes gilvus mounds as an antifungal and antibacterial agent has not been reported. Therefore, in this research, fungus comb extracts' antifungal activity has been tested against $A$. flavus and $A$. niger. Antibacterial activity has been tested against E. coli ATCC 25922, P. aeruginosa ATCC 27853, and S. aureus ATCC 25923.

\section{Material And Methods}




\section{Fungus comb material preparation}

Fungus comb extract was extracted from Indo-Malayan Termite Macrotermes gilvus Hagen (Isoptera: Termitidae) using four different solvents (nhexane, ethyl acetate, methanol, and water), according to Nandika et al. (2021). A sample of $0.5 \mathrm{mg}$ extract was dissolved in $500 \mathrm{~mL}$ of its solvent.

\section{Culturing the bacteria}

Culture of Escherichia coli ATCC 25922, Pseudomonas aeruginosa ATCC 27853, Staphylococcus aureus ATCC 25923 were grown on Nutrient Agar (OXOID, Basingstoke, England) media, and then incubated at $37^{\circ} \mathrm{C}$ for 18 hours. Culture suspensions of E. coli ATCC 25922, S. aureus ATCC 25923 , and $P$. aeruginosa ATCC 27853 were prepared using a physiological solution containing $0.85 \% \mathrm{NaCl}$. The bacterial suspension was then compared with standard McFarland 0.5 solution. This aimed to visually determine the density of bacteria in the suspension with an estimate of having a wavelength of $625 \mathrm{~nm}$ measured using a GENESYS ${ }^{\text {TM }} 150$ Vis/UV-Vis Spectrophotometer.

\section{Antibacterial Susceptibility Assay}

Antibacterial susceptibility assay was detected using the disc diffusion method, according to the standards set by The Clinical Laboratory Standard Institute (CLSI). A hundred microliter of an overnight culture was diluted in saline solution to about $1.5 \times 10^{8} \mathrm{CFU} / \mathrm{mL}(0.5 \mathrm{McFarland}$ turbidity standard). This suspension was flooded into Mueller-Hinton agar (Oxoid Ltd., Basingstoke, UK). The sample's paper disc was dispensed into the inoculated plate and then incubated at $37^{\circ} \mathrm{C}$ for $24 \mathrm{~h}$. The diameters of the clear zones around each paper disc were measured after incubation. Each extract was tested in triplicate.

\section{Determination of the Minimum Inhibitory Concentration (MIC) and Minimum Bactericidal Concentration (MBC)}

Determination of MIC and MBC of antibacterial was carried out by the microdilution method. The microdilution method uses a 96-well microplate (BIOLOGIX, Europe) as the instrument. Each well on the microplate was filled with Mueller Hinton Broth (HiMEDIA, India) media, suspension of E.coli ATCC 25922, P. aeruginosa ATCC 2785, S. aureus ATCC 25923, and fungus comb extract. The number of test microorganisms used in the liquid culture microdilution method has been standardized with a standard turbidity solution McFarland 0.5 . Each well has a different concentration of fungus comb extract, starting from a concentration of $100 \mathrm{mg} / \mathrm{ml}$ to $0.1 \mathrm{mg} / \mathrm{ml}$. The positive control used a medium with the addition of bacterial suspension. The microplate was then incubated at $37^{\circ} \mathrm{C}$ for 18 hours, and then observed the MIC values. Observations were made visually based on turbidity. Turbid indicates the presence of bacterial growth and indicates the media is not overgrown with bacteria. To determine the MBC value, it was done by inoculating bacterial growth results in a microplate on Mueller Hinton Agar (OXOID, United Kingdom) media by adopting the concentration indicated as the MIC value. After incubation for 18 hours at $37^{\circ} \mathrm{C}$, the $\mathrm{MBC}$ value can be seen from the lowest concentration that did not occur in bacterial growth on Mueller Hinton Agar (OXOID, United Kingdom) media.

\section{Culturing the fungi}

The fungi strains of Aspergillus flavus FNCC 6181 and Aspergillus niger FNCC 6114 were grown on Potato Dextrose Agar (MERCK, United States) media, then incubated at $30^{\circ} \mathrm{C}$ for 48 hours and stored in the refrigerator.

\section{Antifungal Susceptibility Assay}

The antifungal activity of fungus comb extracts against $A$. flavus FNCC 6181 and $A$. niger FNCC 6114 cultures was performed by disc diffusion method of Kirby-Bauer using $6 \mathrm{~mm}$ diameter-filter paper discs (OXOID, United Kingdom). First, the cultures were diluted in $1000 \mu \mathrm{l}$ tween solution $0.05 \%$ to prepare a homogenous single-celled suspension. Then, inoculated using streak/spread method on Potato Dextrose Agar (MERCK, United States) medium by sterile cotton bud. The test was carried out with three extract concentrations: $2.5 \mathrm{mg} / \mathrm{ml}, 25 \mathrm{mg} / \mathrm{mL}$, and $50 \mathrm{mg} / \mathrm{ml}$. The susceptibility test was determined by measuring the zone of inhibition $(\mathrm{mm})$ after 48 hours of incubation at $30^{\circ} \mathrm{C}$. The samples were compared to an antifungal agent, 100 units-Nystatin (OXOID, United Kingdom), as a positive control. Each extract was tested in triplicate.

\section{Determination of Minimum Inhibitory Concentration (MIC) and Minimum Fungicidal Concentration (MFC)}

MIC was recorded as the lowest concentration of drug permitting the growth of no spores after 48 hours of incubation at $30^{\circ} \mathrm{C}$ for each fungus comb extract determined by its turbidity. The MIC determination was carried out by microdilution method using a Roswell Park Memorial Institute (RPMI) broth medium (GIBCO, United States) in a 96-well microplate (BIOLOGIX, Europe). A turbid well showed the presence of fungal growth; otherwise, a clear well indicated the absence of fungal growth. Briefly, each well was filled with $100 \mu \mathrm{L}$ broth medium, $100 \mu \mathrm{L}$ samples, then diluted serially twofold, so every well has a varying concentration from $100 \mathrm{mg} / \mathrm{mL}$ to $0.1 \mathrm{mg} / \mathrm{mL}$, and $10 \mu \mathrm{L}$ suspension of $A$. flavus FNCC 6181 and $A$. niger FNCC 6114 . The turbidity was compared by negative control well-containing broth media and suspension and by negative control well-containing broth media only. The experiment was performed four times then continued to determine the MFC value. MFC was recorded as the least extract concentration, showing no visible growth of $A$. flavus FNCC 6181 and $A$. niger FNCC 6114. After determining the MIC value, the solutions in the microplate were used as samples to determine the MFC value. The samples with different turbidity from clear to turbid were streaked on Potato Dextrose Agar (MERCK, United States) then incubated at $30^{\circ} \mathrm{C}$ for 48 hours. 


\section{Results}

\section{Antibacterial activity}

Antibacterial susceptibility assay of fungus comb extracts against Gram-negative (E. coli ATCC 25922 and P. aeruginosa ATCC 2785) and Grampositive ( $S$. aureus ATCC 25923) bacteria were performed using the Kirby-Bauer agar diffusion method. The diameter inhibition zone (DIZ) resulting from the exposure of n-hexane, ethyl acetate, methanol, and water extracts of fungus comb were shown in Table 1. In addition, the clear zone on bacteria tested due to the fungus comb extracts was presented in Figure 1.

A higher dosage of extracts resulted in bigger DIZ in all bacteria tested. Ethyl acetate extract showed the biggest DIZ against all bacteria tested. $S$. aureus ATCC 25923 was the most sensitive to all extracts. Unfortunately, due to the limitation of n-hexane extract, DIZ data of high doses are unavailable for E. coli ATCC 25922 and P. aeruginosa ATCC 2785. Nevertheless, this extract in the lowest dose inhibited S. aureus ATCC 25923 but not others (Figure 1C). Ampicillin and Ciprofloxacin were used as the positive control. Ciprofloxacin in a lower dosage than the fungus comb extracts showed strong inhibition against all bacteria tested. While ampicillin inhibited only E. coli ATCC 25922 and S. aureus (Table 1).

The MIC and MBC test results of ethyl acetate extract showed the smallest concentrations with MIC value of $0.39 \mathrm{mg} / \mathrm{mL}$ and $\mathrm{MBC}$ value of 0.78 $\mathrm{mg} / \mathrm{mL}$ in all bacteria. At the same time, $n$-hexane extract showed MIC and MBC value only on Gram-positive bacteria with the value of $1.56 \mathrm{mg} / \mathrm{ml}$ and $3.13 \mathrm{mg} / \mathrm{ml}$, respectively (Table 2, Figure S1, Figure S2).

\section{Antifungal activity}

In this study, the antifungal activity of fungus comb extracts against $A$. flavus FNCC 6181 and $A$. niger FNCC 6114 was carried out using disc diffusion method Kirby-Bauer and determined by its clear zone diameter $(\mathrm{mm})$ (Table 3 and Figure 2). Ethyl acetate extract exhibited the biggest DIZ against $A$. flavus FNCC 6181 and A. niger FNCC 6114 (Table 3). Methanol and water extracts also inhibited both fungi at high dosage (25 mg and 50 mg). Unfortunately, both fungi were resistant to $\mathrm{n}$-hexane extract. Nystatin at $100 \mathrm{U}$ dosage was used as the positive control.

MIC and MFC investigation supported the antifungal susceptibility assay. The lowest MIC and MFC values were observed for ethyl acetate extract against $A$. flavus FNCC 6181 and $A$. nigerFNCC 6114. Whereas MIC and MFC value of n-hexane extract was not detected for both fungi (Table 4, Figure S3, Figure S4).

\section{Discussion}

In this study, we reported the bioactivity of fungus comb extract from Indo-malayan termite Macrotermes gilvus $\mathrm{H}$. mounds as an antifungal and antibacterial agent against food spoilage microorganisms. Antibacterial activity of fungus comb extracts has been tested against $E$. coli ATCC 25922 , $P$. aeruginosa ATCC 27853, and S. aureus ATCC 25923. In addition, antifungal activity has been tested against $A$. flavus FNCC 6181 and $A$. niger FNCC 6114.

The bacterial inhibitory action of fungus comb extracts has been shown to diverge considerably within species. Ethyl acetate extract displayed the largest diameter inhibition zone (DIZ) against both Gram-positive and Gram-negative bacteria tested, followed by methanol extract and then water extract (Table 1 and Figure 1). Water extract inhibited all bacteria tested at a high dosage of extract but not for the lowest dosage. S. aureus ATCC 25923 was the most sensitive bacteria to all extracts. Unfortunately, n-hexane extract inhibited only gram positive bacteria but not gram negative bacteria. Gram-positive bacteria are generally more sensitive than Gram-negative bacteria due to the lack of an outer membrane (lipopolysaccharide and lipoprotein). In addition, the cell wall architecture of the Gram-positive bacteria tolerates hydrophobic molecules to easily permeate into the cells (Nazzaro et al. 2013).

The microdilution method is used to determine the smallest concentration of antimicrobials to inhibit the growth of microorganisms known as the Minimum inhibitory concentration (MIC). In addition, we also determined the minimum bactericidal concentration (MBC). MBC is the smallest concentration that can inhibit the growth of microorganisms and kill microbes characterized by the absence of colonies on agar media after scraping from each microplate well after incubation (Migliato et al. 2010). The MIC and MBC determination results showed that the ethyl acetate extract exhibited significant antibacterial activity against E. coli ATCC 25922, P. aeruginosa ATCC 2785) and S. aureus ATCC 25923 with respective MIC and $\mathrm{MBC}$ values of $0.39 \mathrm{mg} / \mathrm{ml}$ and $0.78 \mathrm{mg} / \mathrm{ml}$ (Table 2, Figure S1, Figure S2).

Comparable to the antifungal agent such as nystatin, fungus comb extracts showed positive activity on inhibition (Table 3 and Figure 2). The highest antifungal activity could be observed from ethyl acetate extract and followed by methanol. Meanwhile, water extract showed the lowest antifungal activity. Unfortunately, n-hexane extract did not inhibit $A$. flavus FNCC 6181 nor $A$. niger FNCC 6114. The largest DIZ was achieved by fungus comb extracted with ethyl acetate at $50 \mathrm{mg}$ dosage against $A$. flavus FNCC 6181 . The result showed that $A$. flavus FNCC 6181 was more sensitive than $A$. nigerFNCC 6114 (Table 3). The lowest MIC and MFC values were observed for ethyl acetate extract against $A$. flavus FNCC 6181 and $A$. niger FNCC 6114 (Table 4).

The chemical composition of fungus comb ethyl acetate extract has been analyzed previously by Nandika (2021) using the gas chromatography method. The dominant compounds were characterized as glycerol (28.93\%), Phenol, 2-methoxy- (8.54\%), Phenol, 2,6-dimethoxy- (6.55\%) and Bis(2- 
ethylhexyl) phthalate (4.28\%). Whereas n-hexane extract consisted of bis(2-ethylhexyl) phthalate (69.43\%), methyl palmitate (4.55\%), methyl oleate (4.17\%), methyl linolelaidate (2.03\%) and benzenepropanoic acid, 3,5-bis (1,1 dimethylethyl)-4-hydroxy-,methyl ester (1.16\%) as major compound.

Among these compounds, bis(2-ethylhexyl) phthalate (DEHP) is an ester of phthalic acid and naturally synthesized by plants or microorganisms such as fungi or bacteria, which demonstrate different biological activities (Ortiz and Sansinenea 2018). DEHP isolated from Calotropis gigantea plant presented antimicrobial activity against E. coli, S. aureus, Bacillus subtilis, Shigella dysenteriae Shigella shiga, Shigella sonnei, Sarcina lutea, and A. flavus (Habib and Karim, 2009). The fungi also produce this compound. Recently, DEHP was isolated from Aspergillus awamori, displaying antifungal and antibacterial activities against Candida albicans and Gram-positive bacteria Sarcina lutea (Lotfy et al. 2018). Aspergillus fumigatus also secreted DEHP (Abdel-Aziz et al. 2017). Penicillium janthinellum formed DEHP as a major bioactive compound which showed antioxidant, antitumor and antiviral activities (El-Sayed et al. 2015). Actinomycetes (filamentous bacteria) also produce DEHP. Smaoui et al. (2011) isolated DEHP from Streptomyces sp. TN17 showed antimicrobial activities against Gram-positive bacteria and fungi. Similarly, Nocardia levis secreted DEHP that inhibited Gram-positive bacteria and fungi (Kavitha et al. 2009). DEHP is the major component of $n$-hexane extract of fungus comb. We proposed that termite Macrotermes gilvus $\mathrm{H}$. might synthesize DEHP to suppress the growth of another species. Unfortunately, n-hexane extract only inhibited Gram-positive bacteria with MIC of $1.56 \mathrm{mg} / \mathrm{ml}$ and MBC of $3.13 \mathrm{mg} / \mathrm{ml}$ but not fungi Aspergillus. Therefore, there is another compound in the fungus comb that is responsible as an antifungal agent.

Phenolic compound are extensively available in the tissues of plants. This compound also has a critical role to play in highly effective bioactivity. Phenol is a well-known antibacterial agent of phenolic compounds, i.e., 2-methoxyphenol (Guaiacol) and 2,6-dimethoxyphenol (Syringol). Guaiacol and Syringol isolated from wood vinegar of $C$. Japonica showed a strong antimicrobial effect against Pythium splendens, Ralstonia solanacearum, Fusarium oxysporum and Phytophthora capsici. Guaiacol showed MIC of $1.25 \mathrm{mg} / \mathrm{ml}$ against $R$. solanacearum and $P$. splendens and $2.5 \mathrm{mg} / \mathrm{ml}$ against $P$. capsica and F. oxysporum (Hwang et al. 2005). Another study showed antibacterial activity of Litchi chinensis wood vinegar against $S$. aureus, Acinetobacter baumannii and $P$. aeruginosa was due to its highly phenolic compositions such as 2,6-dimethoxyphenol (29.54\%), 2methoxyphenol (12.36\%), and 3,5-dimethoxy-4-hydroxytoluene (11.07\%) (Yang et al. 2016). Ethyl acetate extract of fungus comb also consisted of guaiacol, syringol, and also DEHP. Ethyl acetate extract exhibited both antibacterial and antifungal activity against $S$. aureus ATCC $25923, E$. coli ATCC 25922, P. aeruginosa ATCC 2785, A. flavus FNCC 6181, and A. nigerFNCC 6114. Thus, since both the phenols are contained in fungus comb ethyl acetate extract at relatively high concentrations, they are regarded as major antimicrobial constituents in fungus comb. Application of ethyl acetate extract of fungus comb as antimicrobial agent in packaging material need to be further investigated.

\section{List Of Abbreviations}

E. coli, Escherichia coli

$P$. aeruginosa, $P$ seudomonas aeruginosa

S. aureus, Staphylococcus aureus

A. flavus, Aspergillus flavus

A. niger, Aspergillus niger

MIC, Minimum inhibitory concentration

MBC, Minimum bactericidal concentration

MFC, Minimum Fungicidal Concentration

DIZ, Diameter Inhibition Zone

Amp, Ampicillin

Cipro, Ciprofloxacin

DEHP, bis(2-ethylhexyl) phthalate

Guaiacol, 2-methoxy-phenol

Syringol, 2,6-dimethoxyphenol

ND, not detected

NA, not available

\section{Declarations}


Ethics approval and consent to participate

This article does not contain any studies with human or animal participants performed by any of the authors.

\section{Consent for publication}

All authors consent to the publication of this manuscript.

\section{Availability of data and materials}

The authors declare that data supporting the findings of this study are available within the article and its supplementary information files.

\section{Competing interests}

The authors declare that no competing interests.

\section{Funding}

This study was supported by Gajah Mada University, IPB University, Institut Teknologi Bandung, and Airlangga University, Indonesia, under the Indonesian Collaborative Research Scheme FY 2021 (contract No. 810/UN1.DITLIT/DIT-LIT/PT/2021)

\section{Authors' contributions}

LDW and DN conceived and designed research. KWW, BJA, DCK, IB conducted experiments. Sample collection by AA, LK, DN. LDW, KWW, BJA, DCK, IB analyzed data. LDW, KWW, BJA, DCK wrote the manuscript. AH, LK, AA, IB, DS, YR, DF, IKS, DMH revised the manuscript. All authors read and approved the manuscript.

\section{Acknowledgements}

We are grateful to Anang Juni Yustanto and Th. Novi Dwinawati for technical assistance in laboratory.

\section{References}

1. Abdel-Aziz MS, Ghareeb MA, Saad AM, Refahy LA, Hamed AA (2017) Chromatographic isolation and structural elucidation of secondary metabolites from the soil-inhabiting fungus Aspergillus fumigatus 3T-EGY. Acta Chromatogr 30(4):243-249. doi:10.1556/1326.2017.00329

2. Arango RA (2015) First record of the arid-land termite, Reticulitermes tibialis Banks, in Wisconsin. Great Lakes Entomol 47:211-212

3. Arinana A, Aldina R, Nandika D, Rauf A, Harahap IS, Sumertajaya IM, Bahtiar ET (2016) Termite Diversity in Urban Landscape, South Jakarta, Indonesia. Insects 7(2):20. https://doi.org/10.3390/insects7020020

4. Arshad MA, Schnitzer M (1987) The chemistry of a termite fungus comb. Plant Soil 98:247-256

5. Bbosa GS, Kitya D, Lubega A, Ogwal-Okeng J, Anokbonggo WW, Kyegombe DB (2013) Review of the biological and health effects of aflatoxins on body organs and body systems. Aflatoxins-Recent Advances and Future Prospects. Intech Open Access Publisher, United Kingdom, pp $239-265$. https://doi.org/10.5772/51201

6. Boer SHJ, Boyd-Wilson KSH, Petley M, Walter M (2009) Influence of cold-storage temperatures on strawberry leak caused by Rhizopus spp. NZ Plant Prot 62:243-249. doi:10.30843/nzpp.2009.62.4827

7. Bui-Klimke TR, Wu F (2016) Ochratoxin A and human health risk: A review of the evidence. Crit Rev Food Sci Nutr. doi: 10.1080/10408398.2012.724480

8. Denis N, Zhang H, Leroux A, Trudel R, Bietlot H (2016) Prevalence and trends of bacterial contamination in fresh fruits and vegetables sold at retail in Canada. Food Control 67:225-234. https://doi.org/10.1016/j.foodcont

9. El-Sayed OH, Asker MMS, Shash SM, Hamed SR (2015) Isolation, structure elucidation and biological activity of di-(2-ethylhexyl) phthalate produced by Penicillium janthinellum. Int J Chemtech Res 8(1):58-66

10. Feliziani E, Romanazzi G (2016) Postharvest decay of strawberry fruit: Etiology, epidemiology, and disease management. J Berry Res. doi:10.3233/JBR-150113

11. FAO/WHO (2008) Microbiological risk assessment series 14: Microbiological hazards in fresh leafy vegetables and herbs. Retrieved from ftp://ftp.fao.org/docrep/fao/011/i0452e/i0452e00.pdf

12. Habib MR, Karim MR (2009) Antimicrobial and cytotoxic activity of Di-(2-ethylhexyl) phthalate and anhydrosophoradiol-3-acetate isolated from Calotropis gigantea (Linn.) flower. Mycobiology.. doi:10.4489/MYC0.2009.37.1.031

13. Hwang Y-H, Matsushita Y, Sugamoto K, Matsui T (2005) Antimicrobial Effect of the Wood Vinegar from Cryptomeria japonica Sapwood on Plant Pathogenic Microorganisms. J Microbiol Biotechnol 15(5):1106-1109

14. Kavitha A, Prabhakar P, Vijayalakshmi M, Venkateswarlu Y (2009) Production of bioactive metabolites by Nocardia levis MK-VL_113. Lett Appl Microbiol 49(4):484-490. doi: 10.1111/j.1472-765x.2009.02697.x 
15. Lotfy MM, Hassan HM, Hetta MH, El-Gendy AO, Mohammed R (2018) Di-(2-ethylhexyl) Phthalate, a major bioactive metabolite with antimicrobial and cytotoxic activity isolated from River Nile derived fungus Aspergillus awamori. Beni Suef Univ J Basic Appl Sci 7(3):263-269. doi: 10.1016/j.bjbas.2018.02.002

16. Migliato KF, Mello J, Higa O, Rodas A, Correa MA, Mendes-Giannini MJ, Fusco-Almeida A, Pizzolitto AC, Salgado HR (2010) Antimicrobial and cytotoxic activity of fruit extract from Syzygium cumini (L) Skeels. Lat Am J Pharm 29(5):725-730. doi: 10.33448/RSD-V10I2.12272

17. Nandika D, Karlinasari L, Arinana A, Batubara I, Sitanggang PS, Santoso D, Witasari LD, Rachmayanti Y, Firmansyah D, Sudiana IK, Hertanto DM (2021) Chemical Components of Fungus Comb from Indo-Malayan Termite Macrotermes gilvus Hagen Mound and Its Bioactivity against WoodStaining Fungi. Forests 12:1591. https://doi.org/10.3390/f12111591

18. Nazzaro F, Fratianni F, De Martino L, Coppola R, De Feo V (2013) Effect of essential oils on pathogenic bacteria. Pharmaceuticals 6:1451-1474. doi:10.3390/ph6121451

19. Ortiz A, Sansinenea E (2018) Di-2-ethylhexylphthalate may be a natural product, rather than a pollutant. J Chem. doi:10.1155/2018/6040814

20. Pfliegler WP, Pócsi I, Györi Z, Pusztahelyi T (2020) The Aspergilli and their mycotoxins: metabolic interactions with plants and the soil biota. J Front Microbiol. doi:10.3389/fmicb.2019.02921

21. Smaoui S, Mellouli L, Lebrihi A, Coppel Y, Fguira LFB, Mathieu F (2011) Purification and structure elucidation of three naturally bioactive molecules from the new terrestrial Streptomyces sp. TN17 strain. Nat Prod Res 25(8):806-814. doi:10.1080/14786410902986225

22. Yang J, Yang C, Liang M, Gao Z, Wu Y, Chuang L (2016) Chemical Composition, Antioxidant, and Antibacterial Activity of Wood Vinegar from Litchi chinensis. Molecules 21(9):1150. doi:10.3390/molecules21091150

\section{Tables}

Table 1. Antibacterial Susceptibility Assay

Bacteria strains Diameter of inhibition zone (DIZ) (mm)

Fungus comb extract

Positive control

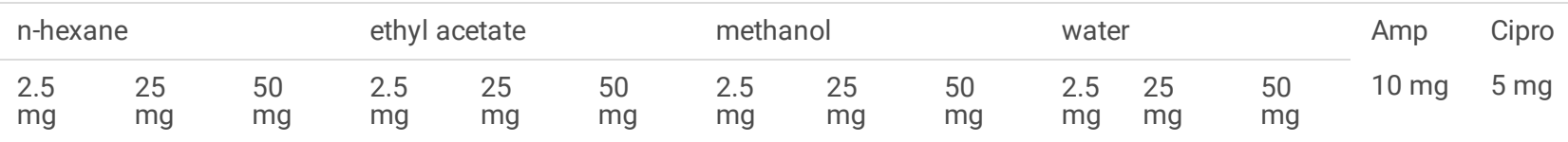

Gram-negative

E. coli ATCC

ND NA NA

NA

$9.85 \quad 28.20 \quad 36.75$

25922

\begin{tabular}{|c|c|c|c|c|c|c|c|c|c|c|c|c|c|c|}
\hline $\begin{array}{l}P . \\
\text { aeruginosa ATCC } \\
25923\end{array}$ & ND & NA & NA & $\begin{array}{l}8.20 \\
\pm 0.14\end{array}$ & $\begin{array}{l}27.65 \\
\pm 0.64\end{array}$ & $\begin{array}{c}32.65 \\
\pm 3.46\end{array}$ & $\begin{array}{l}8.25 \\
\pm 0.07\end{array}$ & $\begin{array}{c}15.05 \\
\pm 1.48\end{array}$ & $\begin{array}{c}31.25 \\
\pm 1.34\end{array}$ & ND & $\begin{array}{l}11.60 \\
\pm 0.85\end{array}$ & $\begin{array}{l}13.10 \\
\pm 3.11\end{array}$ & ND & $\begin{array}{l}29.05 \\
\pm 0.21\end{array}$ \\
\hline
\end{tabular}

Gram-positive

S. aureus ATCC

25923

$\begin{array}{lll}12.95 & 18.45 & 19.40 \\ \pm 0.21 & \pm 0.35 & \pm 0.14\end{array}$

$\begin{array}{ccc}13.75 & 24.95 & 36.75 \\ & \pm 1.63 & \pm 1.63\end{array}$

8.55
\pm 0.49

21.45

33.10

ND

9.25
\pm 1.34

13.25
\pm 1.20

26.75

32.15

Diameter of inhibition zone $(\mathrm{mm})$ presented as means $( \pm \mathrm{SD})$, comprising a $6 \mathrm{~mm}$ paper disk; positive controls were Ampicillin (Amp,10 mg),

Ciprofloxacin (Cipro, 5mg); ND, not detected; NA, not available; three times replication.

Table 2. MIC and MFC value of fungus comb extract against bacterial strains

Bacteria strains

Fungus comb extract

\begin{tabular}{|c|c|c|c|c|c|c|c|}
\hline \multicolumn{2}{|l|}{ n-hexane } & \multicolumn{2}{|c|}{ ethyl acetate } & \multicolumn{2}{|l|}{ methanol } & \multicolumn{2}{|l|}{ water } \\
\hline $\begin{array}{l}\mathrm{MIC} \\
(\mathrm{mg} / \mathrm{mL})\end{array}$ & $\begin{array}{l}\mathrm{MBC} \\
(\mathrm{mg} / \mathrm{mL})\end{array}$ & $\begin{array}{l}\mathrm{MIC} \\
(\mathrm{mg} / \mathrm{mL})\end{array}$ & $\begin{array}{l}\mathrm{MBC} \\
(\mathrm{mg} / \mathrm{mL})\end{array}$ & $\begin{array}{l}\text { MIC } \\
(\mathrm{mg} / \mathrm{mL})\end{array}$ & $\begin{array}{l}\mathrm{MBC} \\
(\mathrm{mg} / \mathrm{mL})\end{array}$ & $\begin{array}{l}\text { MIC } \\
(\mathrm{mg} / \mathrm{mL})\end{array}$ & $\begin{array}{l}\mathrm{MBC} \\
(\mathrm{mg} / \mathrm{mL})\end{array}$ \\
\hline
\end{tabular}

Gram negative bacteria

\begin{tabular}{|c|c|c|c|c|c|c|c|c|}
\hline E.coli ATCC 25922 & ND & ND & $0.39 \pm 0$ & $0.78 \pm 0$ & $1.56 \pm 0$ & $3.13 \pm 0$ & $6.25 \pm 0$ & $12.5 \pm 0$ \\
\hline $\begin{array}{l}\text { P. aeruginosa ATCC } \\
27853\end{array}$ & ND & ND & $0.39 \pm 0$ & $0.78 \pm 0$ & $6.25 \pm 0$ & $12.5 \pm 0$ & $6.25 \pm 0$ & $12.5 \pm 0$ \\
\hline
\end{tabular}

27853

Gram positive bacteria

S. aureus ATCC 25923

$1.56 \pm 0$

$3.13 \pm 0$

$0.39 \pm 0$

$0.78 \pm 0$

$0.78 \pm 0$

$1.56 \pm 0$

$3.13 \pm 0$

$6.25 \pm 0$ 
ND, Not Detected, three times replication

Table 3. Antifungal susceptibility assay

\begin{tabular}{|c|c|c|c|c|c|c|c|c|c|c|c|c|c|}
\hline \multirow[t]{4}{*}{ Fungi strains } & \multicolumn{13}{|c|}{ Diameter of inhibition zone (DIZ) (mm) } \\
\hline & \multicolumn{12}{|c|}{ Fungus comb extract } & \multirow{3}{*}{$\begin{array}{l}\text { Positive } \\
\text { control } \\
\text { Nystatin } \\
100 \mathrm{U}\end{array}$} \\
\hline & \multicolumn{3}{|c|}{ n-hexane } & \multicolumn{3}{|c|}{ ethyl acetate } & \multicolumn{3}{|c|}{ methanol } & \multicolumn{3}{|c|}{ water } & \\
\hline & $\begin{array}{l}2.5 \\
\mathrm{mg}\end{array}$ & $\begin{array}{l}25 \\
\mathrm{mg}\end{array}$ & $\begin{array}{l}50 \\
\mathrm{mg}\end{array}$ & $2.5 \mathrm{mg}$ & $25 \mathrm{mg}$ & $50 \mathrm{mg}$ & $\begin{array}{l}2.5 \\
\mathrm{mg}\end{array}$ & $25 \mathrm{mg}$ & $50 \mathrm{mg}$ & $\begin{array}{l}2.5 \\
\mathrm{mg}\end{array}$ & $25 \mathrm{mg}$ & $50 \mathrm{mg}$ & \\
\hline $\begin{array}{l}\text { A. } \\
\text { flavus FNCC } \\
6181\end{array}$ & ND & ND & ND & $\begin{array}{l}6.67 \\
\pm 0.58\end{array}$ & $\begin{array}{l}45.67 \\
\pm 11.06\end{array}$ & $\begin{array}{l}49.33 \\
\pm 13.43\end{array}$ & ND & $\begin{array}{l}21.33 \\
\pm 7.51\end{array}$ & $\begin{array}{l}23.67 \\
\pm 5.51\end{array}$ & ND & $9 \pm 0$ & $\begin{array}{l}11.67 \\
\pm 3.21\end{array}$ & $\begin{array}{l}17.44 \\
\pm 2.13\end{array}$ \\
\hline $\begin{array}{l}\text { A. niger FNCC } \\
6114\end{array}$ & ND & ND & ND & $9 \pm 10$ & $\begin{array}{l}24 \\
\pm 2.65\end{array}$ & $\begin{array}{l}37.33 \\
\pm 6.43\end{array}$ & ND & $\begin{array}{l}19.67 \\
\pm 2.52\end{array}$ & $\begin{array}{l}22.33 \\
\pm 4.73\end{array}$ & ND & $\begin{array}{l}7.33 \\
\pm 1.53\end{array}$ & $\begin{array}{l}8.67 \\
\pm 0.58\end{array}$ & $\begin{array}{l}24.31 \\
\pm 4.24\end{array}$ \\
\hline
\end{tabular}

Diameter of inhibition zone $(\mathrm{mm})$ presented as means $( \pm S D)$, comprising a $6 \mathrm{~mm}$ paper disk; positive controls were Nystatin 100 unit; ND, Not Detected; three times replication

Table 4. MIC and MFC value of fungus comb extract against fungi strains

\begin{tabular}{|c|c|c|c|c|c|c|c|c|}
\hline \multirow[t]{3}{*}{ Fungi strains } & \multicolumn{8}{|c|}{ Fungus comb extract } \\
\hline & \multicolumn{2}{|l|}{ n-hexane } & \multicolumn{2}{|c|}{ ethyl acetate } & \multicolumn{2}{|l|}{ methanol } & \multicolumn{2}{|l|}{ water } \\
\hline & $\begin{array}{l}\mathrm{MIC} \\
(\mathrm{mg} / \mathrm{mL})\end{array}$ & $\begin{array}{l}\text { MFC } \\
(\mathrm{mg} / \mathrm{mL})\end{array}$ & $\begin{array}{l}\mathrm{MIC} \\
(\mathrm{mg} / \mathrm{mL})\end{array}$ & $\begin{array}{l}\mathrm{MFC} \\
(\mathrm{mg} / \mathrm{mL})\end{array}$ & $\begin{array}{l}\mathrm{MIC} \\
(\mathrm{mg} / \mathrm{mL})\end{array}$ & $\begin{array}{l}\text { MFC } \\
(\mathrm{mg} / \mathrm{mL})\end{array}$ & $\begin{array}{l}\mathrm{MIC} \\
(\mathrm{mg} / \mathrm{mL})\end{array}$ & $\begin{array}{l}\mathrm{MFC} \\
(\mathrm{mg} / \mathrm{mL})\end{array}$ \\
\hline $\begin{array}{l}\text { A. flavus FNCC } \\
6181\end{array}$ & ND & ND & $0.78 \pm 0$ & $1.56 \pm 0$ & $3.13 \pm 0$ & $6.25 \pm 0$ & $25 \pm 0$ & $25 \pm 0$ \\
\hline $\begin{array}{l}\text { A. niger FNCC } \\
6114\end{array}$ & ND & ND & $0.78 \pm 0$ & $1.56 \pm 0$ & $3.13 \pm 0$ & $3.13 \pm 0$ & $12.50 \pm 0$ & $12.50 \pm 0$ \\
\hline
\end{tabular}

ND, Not Detected, three times replication

Figures 


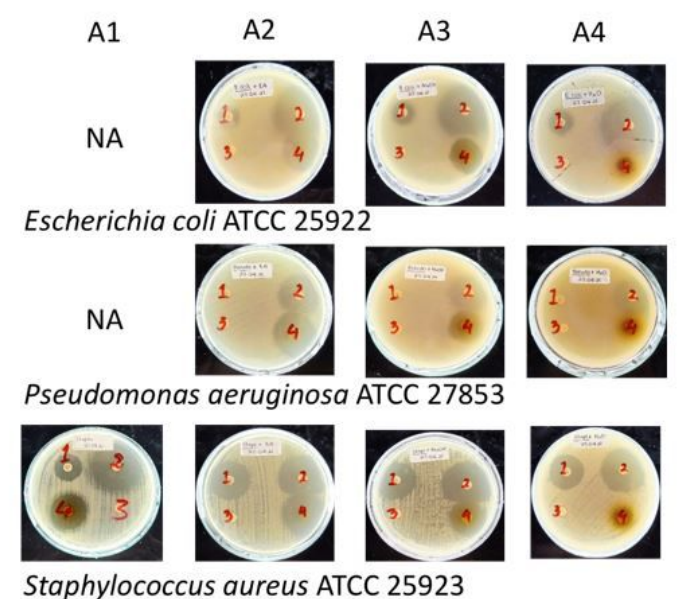

a

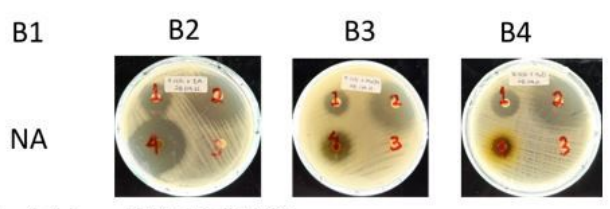

Escherichia coli ATCC 25922

NA

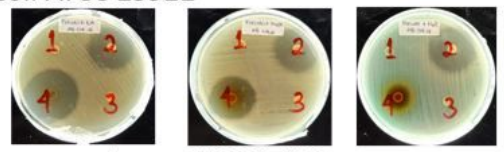

Pseudomonas aeruginosa ATCC 27853

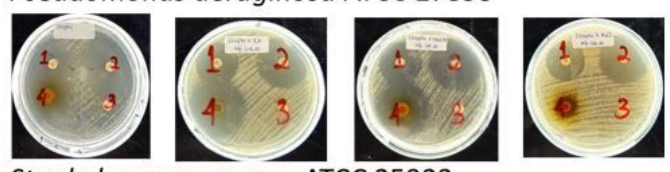

Staphylococcus aureus ATCC 25923

b

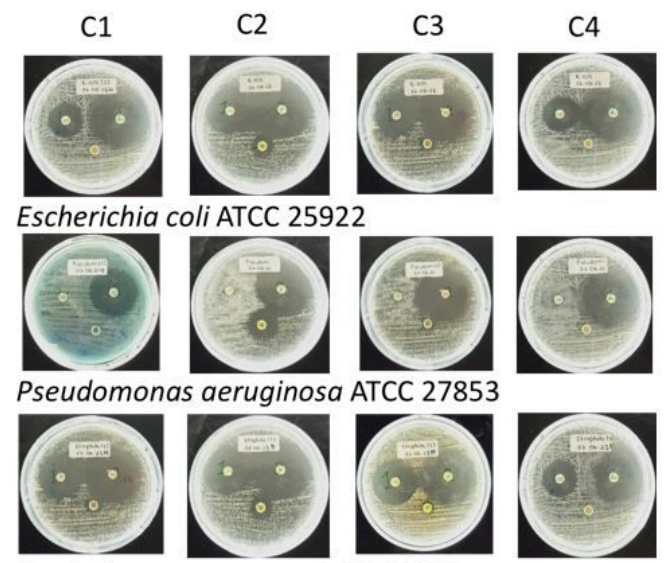

Staphylococcus aureus ATCC 25923

C

Figure 1

Inhibitory activity of fungus comb extract against E. coli ATCC 25922, P. aeruginosa ATCC 27853 and S. aureus ATCC 25923. A1, B1, C1, n-hexane extract; A2, B2, C2, ethyl acetate extract; A3, B3, C3, methanol extract; A4, B4,C4, water extract. a, 50 mg; b, 25 mg; c, 2.5 mg; 1, Ampicillin 10 $\mu$ g; 2, Ciprofloxacin $5 \mu \mathrm{g} ; 3$, negative control (solvent); 4 , fungus comb extracts. 


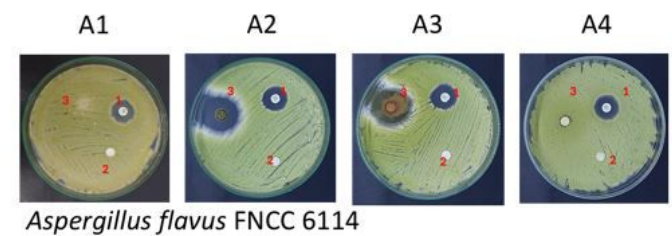

a.

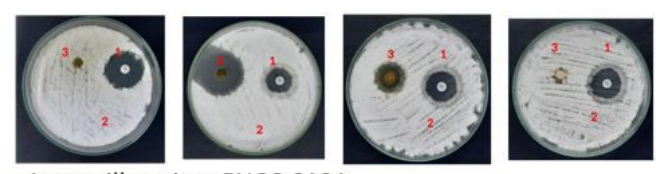

Aspergillus niger FNCC 6181

B1

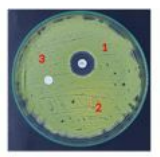

Aspergillus flavus FNCC 6114

b.

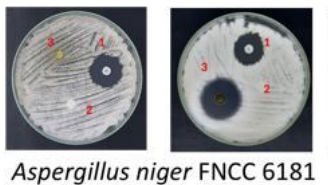

C1

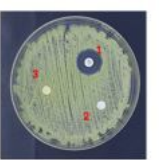

Aspergillus flavus FNCC 6114

c.

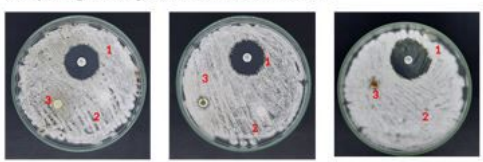

Aspergillus niger FNCC 6181

\section{C2}

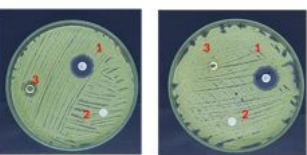

C3
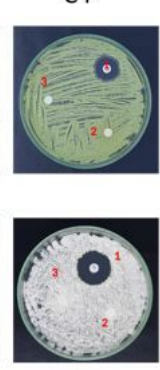

C4

B4
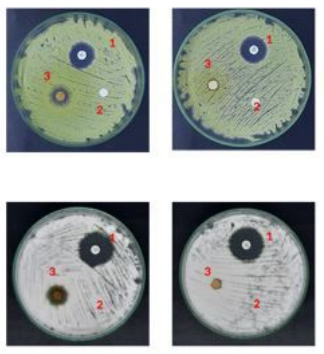

\section{Figure 2}

Inhibitory activity of fungus comb extract against A. flavus FNCC 6181 and A. niger FNCC 6114. A1, B1, C1, n-hexane extract; A2, B2, C2, ethyl acetate extract; A3, B3, C3, methanol extract; A4, B4,C4, water extract. a, 50 mg; b, 25 mg; c, 2.5 mg; 1, positive control (Nystatin); 2, negative control (solvent); 3, sample fungus comb extract.

\section{Supplementary Files}

This is a list of supplementary files associated with this preprint. Click to download.

- graphicalabstract.pdf

- SupplementaryfileAMBexpress.pdf 